\title{
XV. Yüzyılın Ansiklopedisi Dürr-i Meknun ve Dili Üzerine Bir İnceleme
}

\author{
Zeynep Şimşek Umaça, b
}

\section{Özet}

Bu çalışmada, Batı Türkçesinin en önemli devirlerinden olan Eski Oğuz Türkçesinin son döneminde kaleme alınmış bir eser olan Dürr-i Meknun'un dil özellikleri üzerinde durulmuştur. Eser içeriğinin zenginliğinden dolayı yazıldığı dönem için bir ansiklopedi niteliği taşımaktadır. Eserin ait olduğu dönem, Eski Oğuz Türkçesi ile Osmanlıca olarak anılan Batı Türkçesinin olgun yazı dili arasında bir köprü vazifesi görür. Bu çalışmayla geçiş dönemine ait bir eserin dil özelliklerinin ortaya konması amaçlanmıştır. Eser ve yazarıyla ilgili genel bilgiler verilerek de eserin kültür tarihimizdeki yeri hatırlatılmaya çalışılmıştır. Daha önce üzerine çalışma yapılmış bir eser olduğundan bu çalışmada sadece dönemin öne çıkan ses ve şekil bilgisi özellikleri üzerinde durulmuş ve dönemi niteleyen geçiş dönemi özelliklerinin vurgulanması amaçlanmıştır. Eser döneminin özelliklerine uygun olarak Osmanlı yazı diline ait özelliklerin koyulaştığı bir görünümdedir.
Anahtar Kelimeler

Eski Oğuz Türkçesi

Dürr-i Meknun

Klasik Osmanlı Türkçesine

Geçiş

Ansiklopedi

Makale Hakkında

Geliş Tarihi: 01.10.2019

Kabul Tarihi: 24.09.2021

Doi: $10.18026 /$ cbayarsos.627817

\section{Century's Encyclopedia: Dürr-i Meknun and a Study About Its language}

\section{Abstract}

In this article, Dürr-i Meknun's grammatical properties has studied. Dürr-i Meknun was written in Old Oghuz Turkish which is the most important periods of Western Turkish. It is an encyclopedia for the period in which was written due to the richness of its contents. Period of this book is a transition period between the Old Oghuz Turkish to advanced literary language which was called Ottoman Turkish. In this study was aimed to introduce of a transition period's book's grammatical properties. The place of the book in our cultural history was tried to be reminded by giving general information about the book and the author. Because of this book has been studied before, in this study only the prominent phonetic and morphological properties of the period are emphasized it is aimed to emphasize the transition period properties that characterize the period. In accordance with the characteristics of the period, the book appears to have gived point to the features of the Ottoman Turkish literary language.
Keywords

Old Oghuz Turkish

Dürr-i Meknun

Transition to Classical Ottoman

Turkish

Encyclopedia

About Article

Received: 01.10.2019

Accepted: 24.09 .2021

Doi: $10.18026 /$ cbayarsos.627817

a İletişim Yazarı: zeynepsimsekumac@balikesir.edu.tr

b Dr. Öğr. Üyesi, Balıkesir Üniversitesi Fen-Edebiyat Fakültesi Türk Dili ve Edebiyatı Bölümü, ORCID: 0000-0003-2241-2578 


\section{Giriş}

Bu çalışmada, Batı Türkçesinin kuruluş dönemleri içinde tarihlenen bir eserin dil özellikleri üzerinde durulmuştur. Eser yazıldığı devir itibarıyla Eski Oğuz Türkçesinin son dönemi olan Klasik Osmanlı Türkçesine Geçiş dönemine aittir. Bir yazı dilinin kuruluş döneminin son adımını temsil eden bu gibi eserlerde, hem yazı dilinin kuruluş aşamasına ait özellikler hem de olgunlaşmış yazı dilinde yerleşmiş şekiller bir arada bulunmaktadır. Bu çalışmada da bu geçişin izlenebileceği ses ve şekil bilgisi özellikleri değerlendirilmiş, kuruluş aşamasındaki yazı dilinden olgun bir edebiyat diline geçişe dair izler ortaya konmaya çalışılmıştır.

Bunun yanında edebî kaygılar dışında devrin kâinat tasavvurunu -devrin bilim anlayışınıyansıtan bu eser ve yazarı hakkında kısa bilgiler verilerek kültür tarihimizdeki yerinin hatırlatılması amaçlanmıştır.

Eserin incelenmesinde iki ana başlığa yer verilmiştir. Birinci başlık altında Dürr-i Meknun adlı eser ve yazarı kısaca tanıtılıp eserin içeriğine kısaca değinilmeye çalışılacaktır.

İkinci bölümde dil incelemesi yer almaktadır. Burada dil incelemesi yaparken Eski Oğuz Türkçesinin özelliklerinin tanımlanmasında Kaşgarlı Mahmut'un Divanu Lugati't-Türk'te Oğuzların diline dair verdiği bilgiler önemli bir çıkış noktası oluşturur. Buradaki tarihî Oğuzcaya dair ipuçlarıyla Eski Oğuz Türkçesi metinlerine dair çalışmaları birleştiren önemli araştırmacılar, eski Oğuz Türkçesinin özelliklerini ortaya koymuşlardır (Korkmaz, 1975; Ercilasun, 2005; Gülsevin, 2007).

Demirtaş tarafından yapılan imlâ ve ses bilgisi özellikleri incelemesi ile dönemin bir kesiti ortaya konmuş, bu şekilde eserin diğer çalışmalarla birlikte değerlendirilerek Türkiye Türkçesinin tarihî gramerinin oluşturulmasına katkı sağlamak amaçlanmıştır (Demirtaş, 2009, 248). Bu çalışmada ise eserin Eski Oğuz Türkçesinin son dönemine ait olduğu ve Osmanlıcaya geçiş dönemi özellikleri gösterdiği vurgulanmıştır. Eser Eski Oğuz Türkçesi metinlerine ait özelliklerin azalıp Osmanlı yazı diline ait özelliklerin koyulaştığı bir görünümdedir. Çalışmamızda eserin bu yönü incelenip ön plana çıkarılmaya çalışılmıştır. Geçiş dönemi özelliklerinin vurgulanması amaçlanmıştır.

\section{Yöntem}

Eserin yazıldığı dönem itibarıyla bir geçiş dönemi eseri olması ve eski ve yeni şekilleri bir arada bulundurmasından dolayı ağırlıklı olarak bu değişen şekilleri tespit edebileceğimiz özellikler üzerinde durulmuştur. Özellikle Eski Türkçe ile Eski Oğuz Türkçesini birbirinden ayıran özellikler üzerinde durulmuş, bu özelliklerin de Osmanlıca içinde değişime uğrayan şekilleri tespit edilmeye çalışılmıştır.

Çalışmalarında Eski Oğuz Türkçesinin kendi içinde devirlere ayırarak ayrıntılı biçimde incelemiş olan araştırıcıların çalışmalarından yer verdikleri, üzerinde durdukları özellikler hareket noktamız olmuştur. Eserin tam bir imlâ, ses ve şekil bilgisi incelemesi verilmemiş, daha önceki eserlerde de tespit edilen bu dilbilgisel özelliklerin eserin dönemini yorumlamada kullanılması yoluna gidilmiştir. 
Eserin incelenmesinde Demirtaş'ın Süleymaniye Kütüphanesindeki nüshaya dayanarak yaptığı okumalardan yararlanılmış, inceleme sonuçlarından da gerekli görülen yerlerde istifade edilmiştir.

Çalışmada verilen örneklerin tamamı Demirtaş'ın çalışmasından (2009) alınmıştır. Örnekler verilirken el yazması metnin varak ve sayfa numarası verilmiştir. Ayrıca çalışmadaki sayfa numarası belirtilmemiştir.

\section{Bulgular}

\section{Dürr-i Meknun Nedir?}

Dürr-i Meknun, sözcük anlamı olarak "dizilmiş inci" yani "inci dizisi" anlamına gelmektedir. Sıraya koyduğu bilgilerin her birinin bir inci tanesi gibi değerli olduğunu belirtmek isteyen nasir, eserine bu adı uygun görmüştür.

Dürr-i Meknun, XV. yüzyıl Osmanlısının genel kültür konularından olan; geçmiş medeniyetlere ait bilgiler, cennet, cehennem, kıyamet günü tasvirleri, gökyüzündeki yıldızlar ve bunların dünyaya etkileri, yeryüzündeki dağlar, denizler, ırmaklar, adalar ve buralarda yaşayan çeşitli mahlûkatın durumları gibi konuları içeren, bu konuları dinîtasavvufî ve efsanevî kaynaklardan alıp işlemiş olan, bir genel kültür ansiklopedisi niteliğinde Türkçe bir eserdir. Gerek kozmogoniye yer vermesi, gerek yıldızlar ve gökyüzü ile ilgili bilgilerin yer alması ve kendi dışındaki dünyayı tasvir etme çabası eserde coğrafî unsurların çokluğuna yol açmaktadır.

Dinî ve mitolojik motiflerle süslenmiş coğrafya ve seyahat kitapları Arap ve İran edebiyatında yaygın bir tür olarak karşımıza çıkmaktadır. Bunlar daha çok "Acâibü'lBüldan", "Acâibü'l-Hind", "Acâibü'l-Mahlukât" gibi isimler alırdı. Buradaki "acâib" sözcükleriyle "hârikalar, görülmemiş ve duyulmamış garip şeyler" ifade edilirdi. Arap ve İran edebiyatında pek çok örneği bulunan bu türün Türkçe tercümeleri de görülmektedir (Kut, 1988, s.315).

Dürr-i Meknun'un yazarı Ahmet Bican da Kazvinî'nin Acâibü'l-Mahlukât adlı eserinin serbest bir çevirisini yapmıştır. Ancak Dürr-i Meknun içerik olarak bu eserlere benzemekle birlikte telif bir eserdir.

Bu eser yazıldığı yüzyıldan itibaren en çok okunan eserlerden biri olmuştur. Bunu da çeşitli kütüphanelerde bulunan eserin günümüze ulaşmış otuz dokuz nüshasının olmasından anlıyoruz. Bu kadar çok istinsah edilen az sayıda eser vardır. Bu nüshaların dört tanesinin de Topkapı Sarayı Müzesi Kütüphanesinde yer almasından dolayı, Osmanlı Sultanlarının da bu esere yabancı kalmadığı sonucunu çıkarabiliriz. Bu nüshalardan birisi Hanifi Vural tarafından bir makalesinde tanitılmış olan Viyana Flügel Nüshasıdır (2008). Eserin Gaziantep'te elde edilmiş bir nüshası da Tarih Vakfı Yurt Yayınları tarafından "Dürr-i Meknun- Saklı İnciler" adıyla yayınlanmıştır (Sakaoğlu, 1999).

Eserin nüshaları arasında inceleme yapan Ahmet Demirtaş, çalışmasında metni kurarken iki nüshayı esas almıştır. Bunlardan birincisi orijinal nüshaya yakınlık ve devrin dil özelliklerini koruması bakımından tercih edilen Süleymaniye Kütüphanesi Pertevniyal Kitaplığı 456 
numarada kayıtlı nüshadır. Metni kurarken yararlanılan ikinci nüsha ise Topkapı Sarayı Müzesi Kütüphanesi Koğuşlar 916 numarada kayıtlı yazma olarak belirlemiş ve bu nüshalarla kurulan metin üzerine doktora tezi yapılmıştır. Biz de değerlendirmelerimizde Demirtaş tarafından kurulan metinden yararlandık.

Söz konusu nüshalardan Süleymaniye Kütüphanesi Pertevniyal Kitaplı̆̆1 456 numarada kayıtlı nüsha; H.1092/M. 1681 tarihini taşıyan, müstensihinin adı Katib Ahmed olan, harekeli nesihle yazılmış, 162 varaktan oluşan bir nüshadır. Çalışmada yararlanılan bir diğer nüsha olan Topkapı Sarayı Müzesi Kütüphanesi Koğuşlar 916 numarada kayıtlı nüsha; H. 1042/M. 1633 tarihinde İstanbul'da Abdussamed Ali b. Muhammed tarafından istinsah edilmiş, harekeli nesihle yazılmış, baştan bir yaprağı eksik bir nüshadır (Demirtaş, 2009, s.12-13).

\section{Dürr-i Meknun'un Yazarı}

Eserin yazarı Yazıcıŏ̆lu Ahmed Bican, XV. yüzyılda yaşamış aydın bir aileden gelen âlim, mutasavvıf, mütercim ve nasirdir. Babası Yazıcı Salih, ağabeyi ise Muhammediye adlı eseriyle ünlü Yazıcıoğlu Mehmed'dir. Ahmed Bican'ın babası ve ağabeyi Malkara'ya bağlı Kadıköy'den gelip Gelibolu'ya yerleşmiştir. Yazarın, devrin ilimlerini tahsil ettiği ve Arapça ve Farsça'yı iyi bildiği eserlerinden anlaşılmaktadır. Ölüm tarihi kesin olarak bilinmemekle birlikte; babasının "Şemsiyye" adlı eserini 1466'da nesre çevirdiği kabul edilirse takip eden yıllarda vefat ettiği tahmin edilmektedir. (Çelebioğlu, 1989, s.49-51)

Ahmed Bican'ın en bilinen eseri Envarü'l-Aşıkın'dır. Ahmed Bican, ağabeyine “dünyanın vefası olmadığını, geride bir eser bırakmasını" tavsiye eder. O da Arapça bir eser olan Megâribü'z-zaman li gurubi'l- eşyâ fi'l-ayn ve'l-1y'ân adlı eseri yazar. Ahmed Bican bu eserin Türkçeye serbest bir çevirisini yapar, böylece Envarü'l-Aşıkın ortaya çıkar (Çelebioğlu, 1989, s.49-51).

Bir diğer eseri olan Acâibü'l-Mahlukât; Kazvinî'nin aynı adlı kozmoğrafya, coğrafya ve biyolojiye dair eserinin serbest bir tercümesidir (Çelebioğlu, 1989, s.49-51).

Bunların yanında kısaca Münteha adıyla bilinen bir eseri vardır. Bu eser Yazıcıŏlu Mehmed'in, Muhiyiddin İbnü'l-Arabî'nin Fususu'l-Hükem adlı eserinin Müeyyed Cendî şerhine yaptığı, Münteha adlı Arapça şerhin Türkçeye tercümesidir (Çelebioğlu, 1989, s.49$51)$.

Eserlerinde sanat gayesi gütmeyen Ahmed Bican'ın dili son derece sade ve akıcıdır. Genellikle kısa cümleler kullanmışsa da tercümenin gerektirdiği devrik cümlelerin de başarılı örneklerini vermiş, “Türk nesir tarihi açısından ihmal edilmemesi gereken bir isimdir" (Çelebioğlu, 1989, s.49-51).

\section{Dürr-i Meknun'un İçeriğine Dair}

Yazarın eseri yazış amacı; bu eseri okuyanın, yaratılmış olan yerlerden, göklerden, bunların içindekilerden ve ötesinden haberdar olup, yaratılan bu âlemin büyüklüğü ve kusursuzluğu karşısında Allah'ın kudretinin farkına varmasını sağlamaktır. Ayrıca bu karışıklık ve fitne zamanında kısa ömürde insanın gezmesine gerek olmadığını kendisinin pek çok eserden bu 
bilgileri topladığını belirtir günümüzde oldukça yadırganabilecek bu anlayış zamanının şartlarında düşünüldügünde anlamlı olacaktır.

Yazar eserini 18 bölümden, eserdeki adıyla 18 babdan oluşturmuştur. Eserde sırasıyla; gökler, göklerdeki acayiplikler, cennet ve cehennem, ay, gün ve yıldızlar; yerler, yerlerde olan acayiplikler ve cehennem; yeryüzü; iklimler, günler, saatler; dağlar, sular ve adalar; şehirler, ülkeler; mescitler, diyarlar; Süleyman Peygamber ve Belkıs'a ait kıssalar; ömürlerin takdir edilişi; Allah'ın hışmından helak olan yerler; otlar, yemişler, taşlar; Simurg-ı Anka Hikâyesi; kozmogoni; kıyamet alametleri ve münacat bölümleri bulunur. (Demirtaş, 2009, s.92).

Eserin yazılışında dinî bir amaç güdülmüşse de, bunu anlatma vasıtası olarak döneminin coğrafya bilgilerinden yararlandığı görülmektedir. Osmanlı döneminde medreselerde bir ders olarak okutulmayan coğrafya ile ilgili kitap yazmak için pratik veya ilmî amaçlardan önce uhrevi amaçlar gelmekteydi (Gümüşçü, 2006: 69). Allah'ın yarattıklarından insanları haberdar edip, yaratılmışların azametini fark eden insanın yaratıcının azametini görüp iman etmesini ve iyi bir Müslüman olmasını sağlamak ve dünya durdukça bu salih Müslümanlardan hayır dua almak müelliflerin eser vermelerindeki temel amaçtır.

\section{Dürr-i Meknun'un Dili}

Eser Türk dili açısından da önemli bir kaynaktır. Eserin yazıldığı tarihî dönem Türk dili araştırmacıları tarafından yaygın olarak "Eski Anadolu Türkçesi" adıyla adlandırılan dönemdir. "Eski Oğuz Türkçesi" de bu dönemi adlandırmak için kullanılan bir başka terimdir (Ercilasun, 2005, s.442).

XII. yüzyıldan XV. yüzyıla kadar süren ve Oğuz konuşma diline dayalı yazı dilinin kuruluş aşaması olan bu dönem kendi içinde Anadolu'da geçirdiği sosyal ve siyasî aşamalara bağlı olarak dönemlere ayrılmıştır. Bu dönemler; I- Selçuklu Devri Türkçesi, II- Beylikler Devri Türkçesi, III-Klasik Osmanlı Türkçesine Geçiş Dönemidir (Korkmaz, 2005, s.419-423).

Bu dönemlerden ilki; Büyük Selçuklu ve Anadolu Selçuklularının hâkimiyeti devresidir. XI.XIII. yüzyıllar arasında Batı Türkistan'dan Horasan ve Anadolu'ya doğru gerçekleşen Oğuz göçleri sonucunda 1040'da Horasan'da Büyük Selçuklu Devleti, 1077'de de Anadolu Selçuklu Devleti'nin kurulması bu devletlerin kurucusu ve tebaası durumundaki Oğuzların kendi konuşma dillerinin yazı dili olma sürecini başlatmıştır. Ancak bu iki devlette de resmî dilin Farsça, dönemin geçerli bilim dilinin ise Arapça olması bu dönemde halkın konuştuğu Oğuz Türkçesinin yazı dili olma sürecinin başlamasını sağlamış ama gelişmesi yönünde çok büyük katkısı olmamıştır. Dolayısıyla XIII. yüzyıla kadar olan dönemde yalnızca halk için yazılmış dinî veya tasavvufî içerikli daha çok öğretici olmayı amaçlayan eserler karşımıza çıar (Korkmaz, 2013, s.81).

Selçuklu Dönemi Türkçesinin ardından Oğuzcanın yazı dili olma sürecinde önemli bir dönemeç kabul edilebilecek Beylikler Dönemi gelir. Anadolu Selçuklu Devletinin yıkılmasının ardından kurulan Anadolu Beyliklerinin hâkimiyeti altında şekillenen bu dönem XIII-XV. yüzyıllar arasını kapsar. Bu dönem Farsça ve Arapça karşısında Türkçenin hâkim kılındığı, eski şekillerle konuşma diline dayalı yeni şekillerin mücadelesinde yeni 
şekillerin galip geldiği ve böylece Oğuz konuşma diline dayalı bu yazı dilinin olgunlaştığ bir dönem olmuştur (Korkmaz, 2013, s.81).

Eserimizin ait olduğu dönem ise Eski Oğuz Türkçesi içerisinde “Osmanlı Türkçesi'ne Geçiş Dönemi" olarak adlandırılan dönemdir.

Bu dönem XV. yüzyılın ikinci yarısı ile XVI. yüzyıla kadar olan dönemi kapsar. İstanbul'un fethini takip eden dönemde Oğuz Türkçesinin yazı dili olarak yerleşmesi başarıyla tamamlanmıştır. Bu olumlu gelişmenin yanında XVI. yüzyıla kadar Oğuz yazı diline girmemiş Arapça ve Farsça unsurların bu olgunlaşmış yazı dilinde kendine yer bulabildiğini görürüz. Fetih'ten sonra Fatih'in bilim kültür hayatını geliştirme yolunda hız kazandırdığı Arapça, Farsça, Yunanca, Latince gibi dillerden yapılan çeviriler; Arapça ve Farsça unsurların dilimize girmesini hızlandırmış (Korkmaz, 2013, s.110) ancak Dürr-i Meknun gibi eserlerin kaleme alınmasında da ilham kaynağı olmuştur.

Eser yazıldığı dönem itibarıyla yazı dili olma sürecini tamamlamış bir Oğuz Türkçesiyle oluşturulmuştur. Bunun yanında bilim dili Arapçayı ve sanat dili Farsçayı iyi öğrenmiş bir kişi tarafından bu iki dile ait unsurlara da başvurularak yazılmıştır. Bu yönden eserde Eski Oğuz Türkçesini tasvir eden dil özelliklerini ve Arapça, Farsça unsurları görmekteyiz.

Eserin dilinde Eski Oğuz Türkçesine ait kabul edebileceğimiz, bugün yazı dilimizde yaşamayan ya da değişmiş olarak yaşayan ancak ağılarda örneğini bulabileceğimiz örnekler de yer almaktadır. Bunlardan bazılarını şöyle sıralayabiliriz: biti (mektup), buru (sancı), dükeli (hepsi, bütünü), namazlaġı (seccade), ogrı (hırsız), ogur (zaman), pusarık (duman; sis), viribi- (gönder-), isicak (sıcak), isitme (sıtma), vb. (Demirtaş, 2009, s.261-590)

Bunun yanında Kur'an-1 Kerim'den alıntılanan ayetlerden tutun da pek çok insan ve yer ismi aynı zamanda özellikle dini terim adlarının Arapçadan alıntı olduğunu görürüz.

Başta eserin adı olmak üzere Farsça sözcük ve tamlama kullanımının da son derece yaygın olduğu görülmektedir.

Oğuzların kendi şiveleriyle oluşturdukları bir yazı dili olan Eski Oğuz Türkçesinden Türk dünyasının en büyük edebiyat dillerinden birisi olan Osmanlı Türkçesi dönemine geçişin aşamaları son derece önemlidir. Dürr-i Meknun gibi eserler bu geçişin ne şekilde gerçekleştiğini ortaya koyabilecek eserlerdir. O yüzden bu gibi eserler vasıtasıyla Eski Oğuz Türkçesi özelliklerini koruması veya bazı özelliklerin değişim göstererek Osmanlı Türkçesi içinde standartlaşmış şekillere dönüşmesinin izlenebilmesi mümkün olabilmektedir.

Dönemin Öne Çıkan Ses ve Şekil Bilgisi Özellikleri Bakımından Dürr-i Meknun:

\section{Ses Bilgisi:}

a. /ḍ/ > /y/ değişimi

/d/ > /y/ değişimi Eski Oğuz Türkçesini Eski Türkçeden ayıran en önemli özelliklerdendir (Ercilasun, 2005, s.457). 
Korkmaz, Kaşgarlı'nın ḍ > y değişimi hakkındaki açılamasına değindikten sonra Oğuz Türkçesindeki bu değişimin XI.-XIII yüzyıllar arasında tamamlandığını belirtir (2013, s.58).

Eski Türkçe diş arası d'lerin korunduğu örnekler görülmez, metinde bu değişimin tamamen gerçekleştiği örnekler yer alır.

- ... başları 'arşda ayakları tahte's-serādadur... [8a, 14]

○ ... pençelerin açup kuyrukların yire ururlard ... [92a, 9] .

\section{b. Birden fazla heceli sözcüklerin sonundaki G'lerin erimesi}

g ve $\dot{\mathrm{g}}$ seslerinin “(birden fazla heceli sözcüklerde) arkasında yuvarlaklaşmış bir ünlü bırakarak" düşmesi pek çok çalışmada da örneklenmiştir (Mansuroğlu; 1998, s.255)

XIII. yüzyıl sonlarından itibaren G seslerine birden fazla heceli sözcüklerin sonunda rastlanmaz. Sözcüklerin sonundaki G'lerin düşmesi bazı sözcükleri yuvarlaklaştırırken bazısında böyle bir yuvarlaklaşmaya neden olmaz (Korkmaz; 2013, s.59)

Metinde geçen birden fazla heceli sözcüklerin sonundaki g ve g düşmeleri gösterilirken bu seslerin düşmenin yuvarlaklaşmaya sebep olduğu da belirtilmiştir (Demirtaş, 2009, s.53)

○ ... gün țolunsa yatsu olmadın girü șabāh olur... [50a/7-8]

- ... üzerine șaçu șaçdılar idi... [59a/8]

- ... dünya yaradılaldan berü ol kapu açıkdur... [154b/4]

Birden fazla heceli sözcüklerin sonundaki g ve g seslerinin düşmesi sonunda sözcük sonu ünlüsü yuvarlaklaşmaya uğramayan sözcükler de mevcuttur, bunlar da örneklendirilmiştir.

○ ... ölüm uluya ve kiçiye berāberdür ... [100b/6]

- ... cümle katı nesneleri ol deler... [115b/13]

- ... muhît cezîrelerinde taht üzre diri gibi yatur dirler... [93b/2]

$\mathrm{Bu}$ erime neticesinde bazı sözcüklerde ikizleşmeler meydana gelmiştir.(Ercilasun, 2005, s.459)

Bunun örnekleri metinde de bulunur:

- ... ve dahı ağulara aș̣ı eyler ve tūtyā dahı olur... [116a/6]

- ... ġāyet de issi olur... [32a/8]

○ ...ve dahı issi olursa ädeme żarar itmez... [84b/6]

\section{c. Ek ve hece başlarındaki G'lerin erimesi}

Bu değişiklik de XIII. yüzyıl sonlarında tamamlanmıştır (Korkmaz, 2013, s.59)

○ ... eyü kurtıldum senden ... [20b/7]

- ... siçrayup içerü girdi...[94b/2]

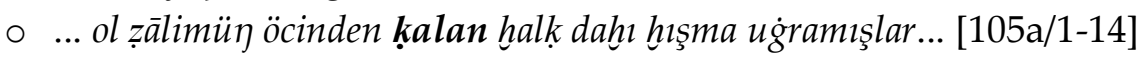


Bu değişmeyi göstermemiş olup da Eski Türkçedeki şeklini koruyan bir örnek de eserde yer almaktadir.

○ ... andan șac iderler üzerinde yufka gibi etmek bişürürler ve kazg்anlarn anda iderler ... $[111 \mathrm{a} / 4-5]$

ḳazgan sözcüğünün kazan anlamı açıktır (Demirtaş, 2009, s.437).

\section{d. Tonlulaşma}

Tonlulaşma Eski Türkçeden Eski Oğuz Türkçesine geçişte özellikle sözcük başında k > g ve t $>\mathrm{d}$ şeklinde gerçekleşmiştir.

\section{$\# \mathbf{k}>\# \mathbf{g}$}

Arap alfabesinde $\mathrm{k}$ ve g seslerinin kef harfiyle gösterilmesi ve metnin imlâ yönünden bu iki sesi ayırıcı bir işaretlemeye gitmemiş olmaması metin neşrini yapan Demirtaş okumalarında bugünkü yazı dilindeki görünüşü esas aldığını belirtir (2009, s.77)

Sözcük başında k sesinin korundu örnekler şöyle sıralanır:

“keserdi, kesilür, keskin, kez, kimesne, kimse, kirpikleri, kirlense, köpük, kötülediler"(Demirtaş, 2009, s. 77)

Sözcük başı g sesiyle okunmuş örnekler de şu şekildedir:

"gebe, geçdiler, geldi, gemi, gerçek, gerek, getürür, gevdesi, geymedi, gezdüm, gibi, gice, girdi, girü, gitdiler, gizledi, göbek, göçeler, gögsi, gök, gölgesi, gönderdi, gö円ül, gördi, göre, gösterür, götüremedi, göz, gözüngü, gücüm, gülerler, gümiş, gün, gündüz, güneş, güzel". (Demirtaş, 2009, s.77-78)

\section{$\# \mathbf{t}>\# \mathbf{d}$}

Eski Türkçedeki sözcük başındaki t sesinin Eski Oğuz Türkçesi metinlerinde korunması veya d sesine dönüşmesi yüzyıllara ve eserlere göre karmaşık bir durum sergiler Daha çok ince sıradan sözcüklerde \#t $>$ \#d değişimi gözlenmesine rağmen bu konuda kurallı bir durumdan bahsedilemez. (Korkmaz, 2013, s.93).

Metinde sözcük başında t sesinin korunduğu sözcükler şöyle sıralanmıştır:

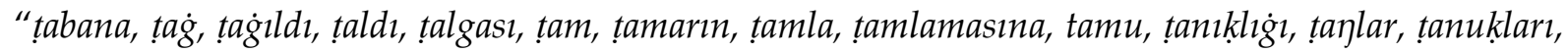
țaparduk, țapdurdl, tapu, țarla, țarliğandl, țarțaǵan, țaş, țaşırdl, țaşmaz, țaşra, țatduralum, țatlu,

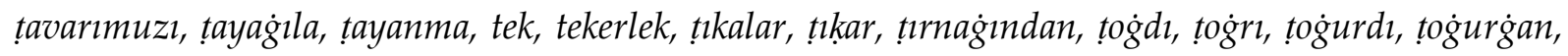

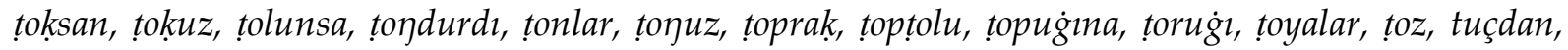
țudaklarına, țul, țutdırup, tutıla, țutındl, țuz, țuzlu, tügi, tükürmesine" (Demirtaş, 2009, s.80-81).

\#t > \#d değişiminin yaşandığı sözcükler de şunlardır:

"dag̀ıdur, dahı, darı, debrenür, degdi, degin, degirmen, degirmi, degme, degül, dek, deler, delik,

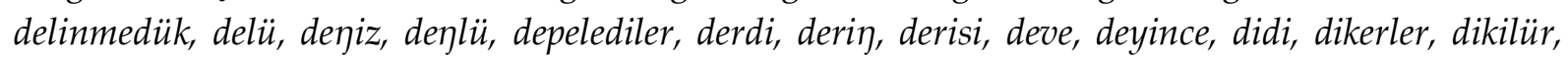
dil, diledi, dilenürler, dilkü, dịleyüp, direk, diri, dirmedi, diş, dişi, ditredi, dizlerine, dolanmış, 
doldurdl, dorusina, dögüp, döker, döndi, dört, döşek, döşeyüp, durak, dügün, dükene, dürlü, dürüp, düşer, düşümi, düzendür"...(Demirtaş, 2009, s.79-80)

Hem \#d'li hem \#t'li şekilleri olanlar şunlardır:

demür / timür depe /tepe doḳın-, tokın- (Demirtaş, 2009, s.78)

\section{e. bol- > ol- Değişimi}

Metnin yazıldığı dönem itibarıyla ol- fiilinin eski şekli olan bol- şekliyle karışık bir kullanımı söz konusu değildir. Metnin tamamında ol- şekli kullanılmıştır.

\section{f. Çift dudak v si olarak nitelenen w'lerin diş-dudak v'sine dönüşmesi.}

Eski Türkçedeki b sesinin değiş̧erek w / v olmasında Oğuz Türkçesi v (diş-dudak v'si) tarafindadır (Korkmaz, 2013, s.57-93)

İlgili değişimi geçirmiş sözcükler metinde diş-dudak v'si iledir.

○ ... anun dört ḳanadı vardur ... [10a/13]

$\circ \quad$... bir kişiye bin altun virdiler ... [76b/15]

○ ... k kașd itdiler ki bir cāleme dahı varalar ... [137a/5]

○ ... evler hāneler itmezler ... [36a/11]

○ ... gemide nūḥ ana yavuz ducā eyledi ... [44b/3]

\section{g. Dudak Uyumu Meselesi}

Bazı eklerin sadece yuvarlak veya sadece düz biçimleri vardır. Eski oğuz Türkçesinde dudak uyumu yoktur. Bu daha çok yuvarlak şekillerin hâkimiyetiyle yuvarlaklaşma şeklinde karşımıza çıkar. Bu Eski Oğuz Türkçesinin en belirgin özelliğidir (Ercilasun, 2005, s.459).

Eski Oğuz Türkçesinde dudak benzeşmesinin olmaması ve ek sonundaki \#g sesinin düşmesi ve öncesindeki düz dar ünlüyü düz yuvarlak ünlüye çevirmesi Eski Oğuz Türkçesindeki pek çok ekin değişiklik geçirmesine neden olmuştur.

Eklerde ortaya çıkan bu yuvarlaklaşma iki başlık altında incelenmelidir:

1. Eski Türkçeden Beri Yuvarlak Olan Şekiller

2. Sonradan Yuvarlaklaşmış Şekiller

Demirtaş çalışmasında "Eklerde Yuvarlaklaşma" başlığı altında Eski Türkçede de yuvarlak ünlülü olan ve bu yuvarlaklığı Eski Anadolu Türkçesinde koruyan ekler sıralanmıştır. (2009, s. 56) Metinde yer alan bu ekler şu şekilde verilmiştir.

“-up, -üp: Zarf-fiil Eki

-duk, -dük: Sıfat-fiil Eki

-ur, -ür, -dur, -dür, -gür: Ettirgen Çatı Eki 
-sun,-sün,-sunlar, -sünler: Emir Eki,

-dur, -dür Bildirme Eki" (Demirtaş, 2009, s.56-59)

Metinde -Up zarf-fiil ekinin bir yerde düz ünlülü, -dUk sıfat-fiil ekinin yüzden fazla yerde yuvarlak ünlülü sadece dört yerde düz ünlülü, -Ur- ettirgenlik ekinin dokuz örnekte düz ünlülü, -dUr- ettirgenlik ekinin beş yerde düz ünlülü, -sUn emir eki beş yerde düz ünlülü, dUr bildirme ekinin düz ünlülü şekline ise sadece bir yerde karşılaşıldığı bilgisi de paylaşılmıştır (Demirtaş, 2009, s.57-59)

Demirtaş çalışmasında "Ünlüsü Sonradan Yuvarlaklaşmış Olanlar" başlığı sonradan yuvarlaklaşmış şekilleri de belirtmiştir. (Demirtaş, 2009, s.59-67)

Bu örnekler Eski Oğuz Türkçesinin son dönemi olan Osmanlıcaya geçiş dönemini işaret etmesi bakımından ve günümüz Türkiye Türkçesinde oturmuş bir uyum olan küçük ünlü uyumunun başlangıç seviyelerini yansıtması bakımından önemlidir. Bu yüzden Eski Oğuz Türkçesinde yuvarlaklaşmış olan ekler üzerinde ayrıntılı biçimde durulacaktır.

Çalışmamızda bu ekler örneklerden yola çıkarak değerlendirilmiştir.

- Birinci Teklik ve Çokluk İyelik Ekleri: $+(\mathrm{U}) \mathrm{m},+(\mathrm{U}) \mathrm{mUz}$

○ ... benüm katumda hācetǖ var mı?... [23a/10]

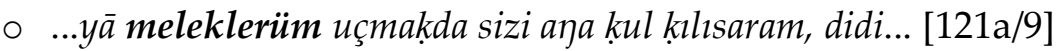

○ ... cilmümüz irdügi kadar bir mikdār beyān eyleyelüm... [2a/14] )

○ ... elbette birimüz furșat bulmaya mı? didi... [124b/8-9]

Birinci teklik şahıs iyelik ekinin yardımcı ünlüsünün 60 kez yuvarlak ünlülü, 42 kez de düz ünlülü olarak kullanıldığ1 tespit edilmiştir (Demirtaş,2009, s.59)

Birinci çokluk iyelik eki ise metinde $69 \mathrm{kez}$ geçmiş, $52 \mathrm{kez}$ "-(1)muz, -(i)müz" şeklinde geçmiştir. Bu kullanıma; cürmimüzi, ḳılarımuz, yüzimüz gibi kullanımları örnek gösterebiliriz. (Demirtaş: 2009, s.60)

- İkinci Teklik ve Çokluk İyelik Ekleri: $+(\mathrm{U}) \mathbf{\eta},+(\mathrm{U}) \mathrm{yUz}$

○ ...dünyā didügü̈y zıll ü hayāl gibidür... [4a/3]

○ ... yā rabbî mūsā senǖ kelîmüy degil miyidi, didiler... [120b/8-9]

- ... bu yajadan deccāl geldi, evleriyüzi hāraba virdi... [148a/7]

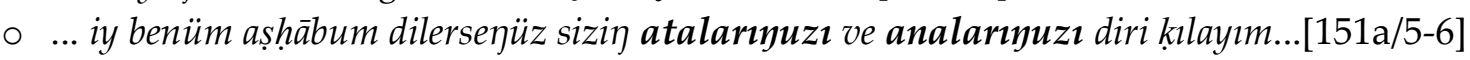

İkinci teklik şahıs iyelik ekinin yardımcı ünlüsünün 79 kez yuvarlak ünlülü, 19 kez de düz ünlülü olarak kullanıldığ tespit edilmiştir (Demirtaş, 2009, s.61)

Metinde 18 yerde tespit edilen ikinci çokluk iyelik eki 13 kez "-(1)nuz, -(i)nüz" şeklinde geçmiştir. (Demirtaş, 2009, s.61)

Gülsevin çalışmasında bu eklerin yuvarlak şekillerini verirken Türkiye Türkçesindeki küçük ünlü uyumunun Eski Oğuz Türkçesinde yerleşmemiş olmasından dolayı bu eklerin yuvarlak ünlü ile kalıplaştığını belirtir (1997, s.12) 


\section{- İlgi Hâli Eki: +(n)Un}

○ ... ol deyizüy yirleri şehristān ve köyler imiş... [108a/3-4]

○ ... ikisinüy dahı şavkı bir dürlü ola... [154a/13-14]

Metinde 946 kez yuvarlak ünlülü olarak geçerken 10 kez de düz ünlülü olarak geçmektedir. (Demirtaş; 2009, s.62)

Eski Oğuz Türkçesi metinlerinde daima dar-yuvarlak biçimde "dudak uyumuna" aykırı kullanımı belirtilen ekin (Gülsevin, 1997, s.25) düzleşmiş örnekleri az da olsa görülür.

\section{- İsimden İsim Yapma Eki: $+1 \mathrm{lU}$}

○ ...arslan șūretlü, fil gevdelü, dört ayaḳlu, başı yağrınında, <ag்zından> odlar șaçılur ve kimi fil dişlü ve fil horțmli... [93a/2-3]

Bu ek 137 kez yuvarlak ünlülü yazılmasına karşıllı 17 kez de düz ünlüyle yazılmıştır (Demirtaş, 2009, s.62)

Eski Türkçede +lIG ekinden ek sonundaki G sesinin düşmesiyle yuvarlaklaşmış olan bu ekin ünlüsü Eski Oğuz Türkçesi metinlerinde kurallı biçimde yuvarlaktır (Gülsevin, 1997, s.118).

Metinde düzleşmiş örneklerin az da olsa görülmesi dudak uyumunun başlangıcını işaret etmesi bakımından önemlidir.

- Görülen Geçmiş Zaman Eki Birinci Teklik ve Çokluk Şahısları ve İkinci Teklik ve Çokluk Şahısları: -dUm, -dUk, -dUn, -dUnUz

- ... bu kez seni bir kişiye virdüm ki ... [90b/9-10]

○ ... ikimiz beraber geldük ammā ben biraz andan öydin geldüm ... [156b/9]

○ ... ol cahdin șlyan ädemmü n nesline virdüy ... [90b/8]

○ ... ya anları neyledüyüz ... [57b/2]

Ek Eski Oğuz Türkçesinde “ötümlülük-ötümsüzlük” uyumuna bağlı değildir. Üçüncü teklik ve çokluk şahıslarda ekin sadece düz şekilleri “-dI” bulunur (Gülsevin; 1997, s.89)

Ekin birinci teklik şahsında düz ünlüyle kullanılan şekle rastlanmazken, yuvarlak ünlüyle 59 kez kullanılmıştır. Birinci Çokluk şahıs çekiminde 39 yuvarlak ünlü kullanıma karşı 4 kez düz ünlüyle kullanılmıştır. İkinci teklik şahıs çekiminde 28 yerde yuvarlak ünlüyle yalnız 1 yerde düz ünlüyle kullanılmıştır. İkinci çokluk şahıs çekiminde ekin hem yuvarlak hem düz ünlü ile kullanılan şekilleri görülmekte fakat görülen geçmiş zaman eki düz ünlü ile kullanılsa bile şahıs eklerinin yuvarlaklığını koruduğu görülmektedir (Demirtaş, 2009, s.64)

\section{- Çokluk Şahıs Eki: $+\mathrm{Uz} /+\mathbf{v U z}$}

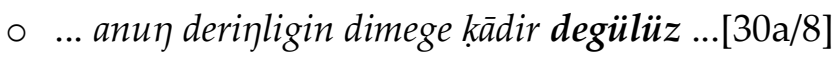

- ... ammā işidürüz ol nice mahlūkāata hükm idermiş...[94b/8]

○ ... biz dahı bilevüz caklı kāmil midür... [96b/6]

○ ... cümlesin dirsevïz kitāba șiǵmaz... [12b/5]

Birinci çokluk şahıs eki -uz /-üz bu yuvarlak ünlülü şekliyle 3 yerde, düz ünlülü -iz şekli bir yerde -eyleriz- geçmektedir. Bildirme ekinin birinci çokluk şahsı görevinde 4 kez yuvarlak 
ünlülü, 2 kez düz ünlülü olarak geçmektedir. $-\mathrm{v} U z$ şeklindeki birinci çokluk şahıs eki 6 yerde yuvarlak ünlüyle kullanılmıştır (Demirtaş, 2009, s.64-65)

- 1. Çokluk Şahıs Emir Eki: -AlUm

- ... gel imdi çık, gidelüm... [43b/3]

○ ... yā varalum veyā ölelüm...[125b/4]

Bu ek metinde 23 kez yuvarlak ünlüyle 7 kez de düz ünlü ile geçmiştir (Demirtaş, 2009, s.65)

- 2. Çokluk Şahıs Emir Eki: -(U)n

○ ... bilüy ki vāhid ü ferdem kimse benden tọgmadı... [3b/2]

○ ... eger inanmazsayuz, gelüy, görüy... [106b/15]

2. çokluk şahıs emir ekinde -nuz şekli sadece bir kez geçerken, yaygın biçimde kullanılan -n ekinin yuvarlak ünlü ile 12 kez geçtiği, düz ünlülü olarak sadece 1 kez geçtiği görülür (Demirtaş, 2009, s.65)

\section{- Geniş Zaman Eki: -(U)r}

- ... her șabāh ol bahre girür, çıkar, silkinür... [10a/8]

- ... ve bir țarafı gelür firengistāna ulaşur... [62b/10]

Gülsevin -(V)r şeklinde gösterdiği bu ekin "dar-yuvarlak” ünlülülü olanlarının tercih edildiğini ifade eder (1997, s. 92)

Düz-geniş a-e vokalli olanları yuvarlaklaşma olayını incelediğimizden değerlendirmemiz dişında biraktık

Geniş zaman eki -r'nin yardımcı ünlüsünün düz olduğu sadece 2 örneğe rastlanırken diğer örnekler yuvarlak ünlülüdür (Demirtaş, 2009, s.66)

- Zarf-fiil Ekleri: -dUkcA, -dUkdA, -(y)U

○ ... içdükce içeceği gelür... [16b/15]

○ ... gücimüz yitdükce binde birin diyelüm... [29b/3]

- ... siz ne dirsiz, didükde begler eyitdi... [94b/5]

- ... ol zamān geldükde allāhuך emriyile biz bunları heläk iderüz... [107a/12-13]

- ... tut habîbüm muhammedǖ emrini diyü buyurıla...[160b/3]

-dIkçA / -dUkçA günümüz yazı diline aynı birleşik şekillerini koruyan zarf-fiiller olarak ulaşmıştır (Gülsevin, 2000) Birleşik zarf-fiiller makalesi Dürr-i Meknun bu ekin dudak uyumuna girme sürecini görebildiğimiz bir metindir.

Metinde -dUkcA zarf-fiil ekinin 12 kez yuvarlak, 13 kez düz ünlülü olarak kullanıldığı; dUkdA ve (y) I / U zarf-fiil eklerinin ise hem düz ünlülü hem yuvarlak ünlülü şekillerinin kullanıldığ tespit edilmiştir (Demirtaş, 2009, s.66-67)

- İsimden İsim Yapım Eki: +cUk

- ... ve dahı bir cānavarcuk vardur ...[22b/3]

- ... ol zamān dāniyāl caleyhi's-selām og̉lancuk idi... [122b/13] 
Bu ek metinde sadece 2 yerde yuvarlak ünlü ile geçer, 12 yerde düz ünlü ile kullanılmıştır (Demirtaş, 2009, s.67)

\section{- Fiilden İsim Yapım Eki: -GUn}

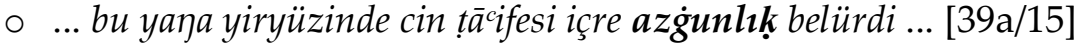

○ ... ol gün güneş kat ıssı ve kıż̇un oldı... [102a/5]

Metinde sadece yuvarlak ünlülü şekilleri mevcuttur (Demirtaş, 2009, s.67).

Bu bilgilerden yola çıkarak eklerin düz ünlülü veya yuvarlak ünlülü kullanımlarını göz önüne serecek bir tablo yaptığımızda şu şekilde bir tablo elde ederiz.

Tablo 1. Eserdeki Eklerin Düz Ünlülü veya Yuvarlak Ünlülü Kullanımı

\begin{tabular}{|c|c|c|}
\hline Ekler & $\begin{array}{l}\text { Yuvarlak Ünlülü } \\
\text { Kullanım Sayısı }\end{array}$ & $\begin{array}{l}\text { Düz Ünlülü Kullanım } \\
\text { Sayısı }\end{array}$ \\
\hline $\begin{array}{l}\text { Birinci Teklik Şahıs İyelik Ekleri: +(I/U)m } \\
\text { (Ekin yardımcı ünlüsü) }\end{array}$ & 60 & 42 \\
\hline Birinci Çokluk Şahıs İyelik Eki: +(I/U)mUz & 69 & 0 \\
\hline $\begin{array}{l}\text { İkinci Teklik Şahıs İyelik Ekleri: +(I/U)n } \\
\text { (Ekin yardımcı ünlüsü) }\end{array}$ & 79 & 19 \\
\hline İkinci Çokluk Şahıs İyelik Eki: +(I)yUz & 18 & 0 \\
\hline İlgi Hâli Eki: +(n)Un & 946 & 10 \\
\hline 1. Çokluk Şahıs Eki: +Uz / +vUz & 3 & 1 \\
\hline Bildirme Eki 1. Çokluk Şahıs: +Uz / +vUz & 4 & 2 \\
\hline $\begin{array}{l}\text { Görülen Geçmiş Zaman I. Teklik Şahıs Eki: } \\
\text {-dUm }\end{array}$ & 59 & 0 \\
\hline $\begin{array}{l}\text { Görülen Geçmiş Zaman I. Çokluk Şahıs Eki: } \\
\text {-dUk }\end{array}$ & 39 & 4 \\
\hline $\begin{array}{l}\text { Görülen Geçmiş Zaman II. Teklik Şahıs Eki: - } \\
\text { dUøUz }\end{array}$ & 28 & 1 \\
\hline Geniş Zaman Eki: -(U)r & Diğer Tüm Örnekler & 2 \\
\hline 1. Çokluk Şahıs Emir Eki: -AlUm & 23 & 7 \\
\hline 2. Çokluk Şahıs Emir Eki: -(u)y & 12 & 1 \\
\hline İsimden İsim Yapma Eki: $+1 \mathrm{U}$ & 137 & 17 \\
\hline İsimden İsim Yapım Eki: +cUk & 2 & 12 \\
\hline
\end{tabular}




\begin{tabular}{lll}
\hline Fiilden İsim Yapım Eki: -gUn & Sadece Yuvarlak Ünlülü & 0 \\
Zarf-fiil Ekleri: -dUkcA & 12 & 13 \\
\hline
\end{tabular}

Kartallığlu'nun Osmanlı Türkçesi döneminde dudak uyumunun gelişme seyrini takip ettiği çalışmasında "U Sınıfı Ekler" olarak belirtmiş olduğu ekler burada "Ünlüsü Sonradan Yuvarlaklaşmış Ekler" içerisinde bahsedilen eklere uymaktadır. 16. yüzyılda başlangıç aşamasında olan dudak uyumu, 17. yüzyılda gelişme göstermiş ve 18. yüzyılda ise yerleşmiştir. Dudak uyumu bakımından 16. yüzyılda eklerin büyük oranda Eski Oğuz Türkçesindeki şekillerini koruduğu görülürken, dudak uyumuna giren şekiller de bu yüzyılda görülmeye başlanmıştır (Kartallığlu, 2008, s.478).

Tablo incelendiğinde eserin dilinde dudak uyumunun başlangıç aşamasında olduğu görülür. Eserin yazıldığı dönem dikkate alındığında bu beklenen bir durumdur.

\section{h. Ünsüz Uyumsuzluğu}

Bugünkü anlamda bir ünsüz uyumun bulunmayı günümüz de ünsüz uyumuna bağlı olarak $\mathrm{t}$ sesi ile de başlayabilen eklerin sadece d'li şekillerinin bulunması da Eski Oğuz Türkçesine özgü bir özelliktir (Ercilasun, 2005, s.459).

Sürekli ötümsüz bir ünsüzle başlayarak ünlü-ünsüz uyumsuzluğuna sebep olan ekler Gülsevin ve Boz'un çalışmasında da sıralanmıştır (2004, s.96).

Eserin inceleme bölümünde tek şekilli olduğu ve ünsüz uyumu dışında kaldığg belirtilen, $d$ ünsüzü ile yazılan ekler örneklenmiştir.

“-dı, -di: Görülen Geçmiş Zaman Eki”: açdı, ögretdi, uçdı, ...

“-duk, -dük: Sıfat-fiil Eki”: geçdügin, yapduğı, itdügi, ...

“--dur, -dür: Ettirgen Çatı Eki": itdürür, ekdürdi, tatdurdık, ...

“-dur, dür (-durur, -dürür) Bildirme Eki”: açıkdur, dörtdür, yüksekdür, ...

“-da, -de: Bulunma Hâl Eki": beşikde, uçmakda, vaktde,...

“dan, -den: Ayrılma Hâl Eki”: ag̉açdan, ıraḳtan, ümmetden, ... (Demirtaş, 2009, s.82-84).

\section{Şekil Bilgisi}

\section{a. Çıkma Hâli Eki}

Çıkma hâli ekinde +DIn > +dAn şeklinde bir değişim görülür. (Ercilasun,2005, s.459).

+dIn şekli Eski Oğuz Türkçesi için karakteristik olmayan, seyrek görülen bir şekildir. Kullanımı ön sözcüğü ve bazı edatlarla sınırlıdır (Gülsevin, 1997, s.57). 
Çıkma hâli ekinin metnin tamamında d sesiyle ötümlüleşmiş olarak kullanıldığ1 "İmlâsı Kalıplaşmış Ekler" içinde yer verilerek belirtilmiştir (Demirtaş, 2009, s.82). Ekin vokalinde de I > A değişimi gerçekleşmiştir. Metinde aksine bir örneğe rastlanmaz.

○ ... hak tacālā ädemi balçıkdan yarattı ...[39b/10]

○ .... cemic ümmetden öy muhammed ümmeti uçmağa giriserdür...[48a/6]

\section{b. Yükleme Hâl Eki}

Yükleme hâli eki $+g$ erimiş, $+g$ 'dan önce yer alan ünlü yükleme hâli eki görevini üstlenmiştir.(Ercilasun, 2005, s.459).

Eski Türkçedeki +(I/U)G terk edilmiş, Eski Anadolu Türkçesinde +(y)I şekli kullanılmıştır. III. Teklik iyelik ekinin üzerine eksiz yükleme hâli gelir (Gülsevin, 1997, s.31-32).

○ ... hilāfet yüzügin süleymana ilet... [81b/9]

○ ... kafirler șulhıın boza ... [147a/6]

○ ... halkını kırmak kașdın eyledi ... [83b/10]

○ ... dāb deyince günāhı yüklendik ... [159b/3]

\section{c. Vasıta Hâli Eki}

Vasıta hâli eki +n'nin kullanımı düşmüştür. İle edatının ekleşmesiyle oluşan +lA şeklinin kullanımı yaygınlaşmıştır (Ercilasun, 2005, s.459).

○ ....hak tacālā riyayıla olan cameli kabul eylemez... [2b-10-11]

- ... anuy-ıla bile tesbîh iderler... [8b-13]

+n vasıta hâli eki daha çok kalıplaşmış yer ve zaman zarfı olarak kullanılmıştır (Korkmaz, 2013, s.98-99)

○ ... yazın țaşar, kışın kan akar... [49a/12]

○ ... sîmurğ-ı cankā gündüzin süleymān h̆ımetinde, gice gelir ḳız ile olurdu... [133a/8]

\section{d. Şahıs Eklerinin Durumu}

Eski Oğuz Türkçesinde zamir kökenli teklik 1. şahıs eki -vAm ve -Am'dır, -vAn ve -Im şekilleri de görülür (Korkmaz, 2013, s.98-99).

Metinde -vAm ve -vAn şekilleri yer almaz. Yazı dilindeki gelişmeye bağlı olarak çok şekillilikten ses uyumlarına bağlı istikrarlı şekillere geçiş yaşanmıştır.

○ ... anuך göjlindekin ben bilürem ... [43a/9]

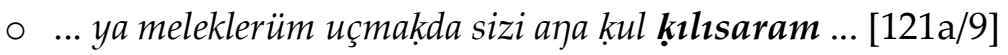

- ... yā cāzrācil dilerem beni uçmağa iledesin uçmağ görem [43a/ 11-2]

- ... yā fātıma, yedi yıldır ben beyābānda gezerim ... [28b/9]

Çokluk 1. şahıs eki-vUz, -Uz şeklindedir (Ercilasun, 2005, s.460; Korkmaz, 2013, s.98)

Metinde bu şekillerin örnekleri görülür.

○ ... yıldızları yirlü yerinde göreler, ne az uyumışuz diyeler ...[154a/6] 


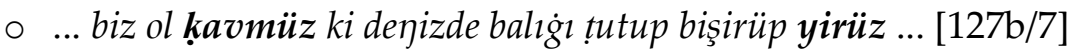

- ... biz dahı bilevïz aklı kāmil midür ... [96b/6]

- ... lāzımdur ki varup görevïz ...[131a/3-4]

İyelik kökenli 1. Çokluk şahıs eki -mIz yerine $-\mathrm{k}$ şeklinde kullanılır olmuştur. (Ercilasun, 2005, s.460)

○ ... kürsîden eyitdük uçmaǵa geldük ... [12b/7]

○ ... seni hep cümle çeri门 ile devşirüp kavmimüze iledürdük ... [127b/12]

Şart ekinin 1. Çokluk şahıs çekiminde hem zamir kökenli hem de iyelik kökenli şekiller kullanılmıştır. Eserin bu iki şeklin birlikte kullanıldığı bir geçiş döneminin mahsulü olduğunu ifade etmek için bu örnekler uygundur.

○ ... cümlesin dirsevüz kitäba șig̀maz ... [12b/5]

- ... biz dahı bilevïz caklı kāmil midür ... [96b/6]

○ ... zîrā iki üç günlik yoldan bir mu'azzam nesneye baksak bir güçicek nesne görinür ... [22a/3]

○ ... ol ki cāhildür biך bunuך gibi dirsek kulaġına girmez ... [159a/12]

\section{e. Gelecek Zaman Eki}

Gelecek zaman eki olarak -IsAr kullanılır (Ercilasun, 2003, s.460).

Gülsevin'in çalışmasında da bu ek en işlek gelecek zaman eki olarak belirtilir (1997, s.100)

Eski Anadolu Türkçesinin bu karakteristik eki metinde sıkça kullanılmıştır.

- ... her kişi hayr ve şer her ne itdiyise bir bir șorllup cezāsın bulısardur ... [158a/ 9-10]

- ... ol dahı mevt şarābın içiserdür ... [120a/10-11]

-AcAk şeklinin gelecek zaman çekiminde kullanımına örnek teşkil edebilecek şu cümle, yeni şekillerin yazı diline nasıl yavaş yavaş dahil edildiğini gösterir niteliktedir.

○ ... üzerine dürlü șūretler kendünden kazmışlar bu cäleme enbiyādan ve beglerden kimler geldi ve kimler gelecekdür... [78a/1]

\section{f. İstek Eki}

Eski Türkçenin gelecek zaman eki -gA, -a'ya dönüşmüş ve istek fonksiyonunda kullanımı yaygınlık kazanmıştır (Ercilasun, 2005, s.460).

Gelecek zaman fonksiyonu yanında geniş zaman ve şimdiki zaman da gösterebilen, Eski Türkçedeki -gA'dan gelen -(y)A ekinin istek fonksiyonu yaygınlık kazanmıştır (Gülsevin, 1997, s.125).

Eserde istek kipi kullanımı yaygındır.

○ ... ol dahı getüre ... [134a, 15]

○ ... uymayan cehennem diyü aja bırag்a, ol aja cennet ola ... [150b, 8-9] 


\section{g. Ek-Fiil}

Ek-fiilde er- > i- değişimi gerçekleşmiştir. (Ercilasun, 2005, s.460).

- ... carafatuך öte uctnda idi [84a-13]

- ... hergiz caynma almaz idi ... [39a/11]

\section{h. Bildime Eki}

Ek-fiilin şimdiki zamanı III. Teklik şahsında görülen turur şekli tonlulaşarak durur şekline geçmiş, aynı zamanda ekleşerek bildirme eki -dur şeklini almıştır (Ercilasun, 2005, s.460).

○ ... yā İskender kuvvet ve kudret benümdür ... [38a/4-5]

- ... ve bir böyük cezîre vardur ... [66a/7]

-dur şeklinin yaygınlaşmasına rağmen eserde dört kez durur şeklinin geçtiği örneklere de rastlanir. (Demirtaş, 2009, s.59).

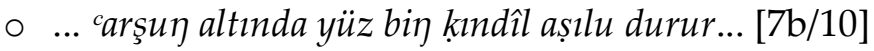

- işleri anuך kamu hikmet durur her ne bakarisaך ibret durur [56b/1-2]

Aşağıdaki örnekte ise dur-filinin yardımcı fiil olarak kullanılıp ekleşmesinden çok gerçek fiil anlamını koruduğu düşünülebilir.

- ... anlar ki risālete irmedi, millet ve mezheb nedür bilmezler, hayvān gibi dururlar [52a/12]

\section{Yeterlilik Yardımcı Fiilinin Olumsuz Şekli}

Karahanlı Türkçesi eserlerinden itibaren takip edilebilen bil- yeterlilik yardımcı fiilinin olumlu şekli Eski Oğuz Türkçesi eserlerinde de karşımıza çıkar. Yeterlilik yardımcı fiili ile ilgili asıl dikkat çekici nokta; Eski Oğuz Türkçesi metinlerinde Harezm sahasında yazılmış Türkmen ve Kıpçak özellikleri de taşıyan eserlerde körlenmiş olan u- yardımcı fiili ile yapılan yeterliliğin olumsuz şeklinin tekrar ortaya çıkmasıdır (Korkmaz, 1988, s.112)

Korkmaz, -uma- yardımcı fiilinin III.-XVI. yüzyıllar arasında üç farklı gelişme merhalesi gösterdiğini ancak bunların kronolojik olarak bir sıraya sokulmasının pek mümkün görünmediğini belirtmiştir. Bu merhaleleri kısaca şöyle özetleyebiliriz:

I. -U zarf-fiil ekinin U- yardımcı fiiliyle kaynaştığı böylece esas fiille kaynaşıp ekleştiği merhale: -UmA- "bulumadım, bilümedi"

II. -U zarf-fiili ekinin eklendiği fiile uyuma girerek düzleştiği merhale: “doyımaz, getürimez"

III. -I zarf-fiil eklerinin genişleyerek -A şekline geçtiği merhale: “alamadı, sökemez" (1988, s.113-114)

Eserde yeterlilik fiilin olumsuz şekli kullanılırken II. ve III. merhale olarak ifade edilen şekilleri tespit etmek mümkün olabilmektedir. 
- ... niçe pādişāhlar kaṣd itdiler anı alımadılar... [103a/8]

- ... āhir zamanda cümle memleketleri alıcak an alımayalar... [116b,6]

○ ... her kim mūsāyı tuta veyāhud öldürebilürse kızım ała vireyim ... [124b/12]

○ ... ben eglenemezem yalınuz... [134a/14]

Bil- yeterlilik yardımı fiili kullanılırken de zarf-fiil ekinin düzleştiği bir örneğe rastlanmıştır.

○ ... habeşten ilerü kıışın varıbilürler șusızlıkdan... [42b/10]

Bu örnekler de Eski Oğuz Türkçesinde yaşanan değişimi göstermektedir.

\section{i. -IçAk Zarf-fiil Eki}

Eski Anadolu Türkçesine has olan -IçAk zarf-fiili kullanılmıştır (Ercilasun, 2005, s.460).

Bu zarf-fiil eki Eski Anadolu Türkçesini en işlek zarf-fiil eklerindendir. Gülsevin tarafından da "Müstakil Eklerle Yapılanlar" başlığı altında "Orjinalde Zarf-fiil Eki Olanlar" şeklinde sınıflandırılmıştır (1997, s.125).

Metinde örneklerine rastlanır.

○ ... ol ocak söyünicek devlet horasana intikāl itti ... [146b/12]

○ ... kubbeye gelicek micmārn gāàyib oldı [86b/11]

\section{Sonuç}

Bu eser XV. yüzyıla ait Osmanlı sahasında yazılmış, döneminin dil malzemesini yansıtan bir eser olarak dilbilim çalışmaları için önemli bir kaynaktır.

Eserin yazıldığı dönem Oğuz Türkçesinin bir yazı dili haline gelişinin tamamlanmış olduğu devredir.

Eserin yazıldığı XV. yüzyılın ikinci yarısı Türkoloji literatüründe Eski Oğuz Türkçesinin üçüncü ve son evresi olan Osmanlıcaya geçiş dönemi olarak nitelendirilmektedir. Bu devrede Eski Oğuz Türkçesinin, Osmanlıcaya -daha doğrusu günümüz Türkçesinetaşınmayacak olan ses ve şekil özelliklerinde önemli miktarda azalma görülür. Osmanlıca içinde yaşamaya devam edecek özelliklerin ise korunduğu görülür.

İncelemiş olduğumuz eser de bu yönüyle devrinin özelliklerini yansitan bir eserdir. Eserde Eski Oğuz Türkçesi için standart kabul edilen şekiller ve yeni şekiller yan yana görülür. Durumun eski veya yeni şekillerin lehine olması konusu ise özelliklere göre farklılık gösterir. Kök ünlüsünden sonraki d ünsüzlerinin y'ye dönüşmesi, ek ve hece başı g'lerin erimesi, tonlulaşma, ol- şeklinin kullanımı istisnasız bir şekilde gerçekleşirken; dudak uyumunun başlangıç aşamasında olması, zamir kökenli teklik 1. şahıs ekinin -Am şekline dönmüşken zamir kökenli çokluk 1. şahıs ekinin hem $-\mathrm{Uz}$ hem de $-\mathrm{vUz}$ şeklinde görülmesi, gelecek zamanda bir örnekte de olsa -AcAk şekline rastlanması geçiş dönemini açıkça takip edebileceğimiz örneklerdir. 


\section{Kaynakça}

Çelebioğlu, A. (1989). Ahmed Bican Maddesi. İslam Ansiklopedisi C. 2, (s. 49-51), İstanbul: Diyanet Vakfı Yayınları

Demirtaş, A. (2009). Yazıcıŏ̆lu Ahmed Bîcan Dürr-i Meknun (Tıpkıbasım, İnceleme, Çevriyazı, Dizin). İstanbul: Akademik Kitaplar.

Ercilasun, A. B. (2005). Türk Dili Tarihi. Ankara: Akçă̆ Yayınları

Gülsevin, G., \& Boz, E. (2004). Eski Anadolu Türkçesi. Ankara: Gazi Kitabevi

Gülsevin, G. (1997). Eski Anadolu Türkçesinde Ekler. Ankara: Türk Dil Kurumu Yayınları

Gülsevin, G. (2000). Türkiye Türkçesinde Birleşik Zarf-fiiller. Afyon Kocatepe Üniversitesi Sosyal Bilimler Dergisi 5, 122-143.

Gülsevin, G. (2007). Oğuzca Olmayan Tarihî Metinlerde Oğuzca Unsurlar ve Nehcü'l-Feradis Örneği. 46. Uluslararası Altaistik Konferansı (PİAC), 22-27 Haziran 2003, Ankara: Türk Dil Kurumu Yayınları

Gümüşçü, O. (2006). Tarihî Coğrafya. İstanbul: Yeditepe Yayınevi

Kartallığlu, Y. (2008). Osmanlı Türkçesindeki Ekler Dudak Uyumuna Göre Nasıl Okunmalıdır? Turkısh Studies 3(6), 458-481. Retrieved from http://dx.doi.org/10.7827/TurkishStudies.471

Korkmaz, Z. (1988). Türkiye Türkçesinde "iktidar" ve "İmkân” Gösteren Yardımcı Fiiller ve Gelişmeleri. Türk Dili Araştırmaları Yıllı̆̆ı Belleten 1959, 107-124. Ankara: Türk Dil Kurumu Yayınlar1

Korkmaz, Z. (1975) Eski Türkçedeki Oğuzca Belirtiler. Bilimsel Bildiriler 1972- I. Türk Dili Bilimsel Kurultayına Sunulan Bildiriler, Ankara: Türk Dil Kurumu Yayınları

Korkmaz, Z. (2005). Anadolu Yazı Dilinin Tarihî Gelişmesinde Beylikler Devri Türkçesinin Yeri. Türk Dili Üzerine Araştırmalar Birinci Cilt, Ankara: Türk Dil Kurumu Yayınları

Korkmaz, Z. (2013). Oğuz Türkçesinin Gelişimi. Ankara: Türk Dil Kurumu Yayınları

Kut, G. (1988). Acâibü'l-Mahlûkat Maddesi. İslam Ansiklopedisi C. 1, (s. 315-317), İstanbul: Türkiye Diyanet Vakfı Yayınları

Mansuroğlu, M. (1988). Eski Osmanlıca. Tarihi Türk Şiveleri, Mehmet Akalın (haz.). Ankara: Türk Kültürünü Araştırma Enstitüsü Yayınları Ankara.

Sakaoğlu, N. (1999). Dürr-i Meknun Saklı İnciler. İstanbul: Tarih Vakfı Yurt Yayınları

Vural, H. (2008). Yazıcızade Ahmed Bican'ın Dürr-i Meknun Adlı Eseri Üzerine. Türk Dili Araştırmaları Yıllığı Belleten 2008-1, 127-134, Ankara: Türk Dil Kurumu Yayınları 